\title{
Os rios (lagos e lagoas) dos peixes mortos
}

\author{
Berenice Gehlen Adams \\ (Especialista em Educação Ambiental - UFSM) \\ http://projetoapoema.blogspot.com/ \\ e-mail: bere@apoema.com.br
}

Repete-se um terrível episódio de mortandade de peixes no Rio dos Sinos (RS). Sem as mínimas condições de vida, os peixes agonizam e morrem sufocados. Alguns dizem que a falta de oxigenação da água do rio é decorrente das faltas de chuva na região, outros apostam que é pela poluição, pois, além da grande quantidade de esgoto que recebe, empresas calçadistas e de outros setores despejam seus rejeitos (de forma clandestina), há muito tempo, em várias veias que desembocam no leito do rio.

Quem navega de vez em quando pelas águas do Rio dos Sinos já o conhece muito bem, pela sua cor e pelo seu cheiro, e seria ingenuidade atribuir mais este desastre à natureza. Por mais que possam dizer que seja um desastre climático, a natureza não é a vilã dessa história, mas sim, uma vítima que não pode se defender.

Pesquisando na Internet (especificamente no buscador Google) percebi que não é mais um fato raro ocorrerem mortandades de peixes no País, pelo contrário! São muitos os casos, evidenciando - enorme descaso com nossos recursos hídricos, uma vergonha sem tamanho.

A camuflagem está em toda parte na área da produção quando se fala em atividades industriais ambientalmente corretas. Há até quem queira ser sério e criterioso, impedindo ações industriais predatórias, mas laudos são assinados por técnicos de meio ambiente em nome de garantia de emprego, e assim seguimos devastando o mundo que clama por socorro e que, como resposta, só encontra o eco vazio do seu grito.

As informações que encontrei sobre peixes mortos mostram números assustadores e nos indicam que a hora de agir já passou, e faz tempo. Confesso que me assustei com este pequeno levantamento, vejam: 
- RS - Peixes mortos no Rio dos Sinos chegam a pesar 15 toneladas (Zero Hora - 03/12/2010)

- SE - Peixes mortos no rio do Sal Aracaju - (Clik Sergipe $03 / 12 / 2010$ )

- SP - Peixes mortos do Atibaia (Cosmo - 03/12/2010)

- RS - Peixes mortos à orla do Laranjal - Pelotas (ClikRBS $17 / 11 / 2010)$

- RS - Peixes mortos são retirados de arroio em Sapiranga (Jornal VS - 22/11/2010)

- RJ - Uma tonelada de peixes mortos em Piratininga (A Tribuna - 18/11/2010)

- CE - Após morte de peixes, laudo técnico constata poluição de Lagoa da Precabura (Verdes Mares - 20/10/2010)

- RS - Peixes mortos são encontrados no Rio Gravataí, em Canoas (Diário de Canoas - 25/10/2010)

- SP - Amma investiga causa da mortandade de peixes na região de Campinas (Meia Ponte.org - 28/10/10)

- RS - Prefeitura recolhe peixes mortos em Canoas (Correio do Povo - 24/08/2010)

- SP - Peixes mortos e água poluída preocupam moradores de Hortolândia (TVB - 12/07/2010)

- ES - Desastre ambiental: Milhares de peixes mortos no Rio São Sebastião (Ururau - 26/07/2010)

- BA - Peixes mortos e população sem água em Floresta Azul ( A Tarde On-Line - 14/04/2010)

- ES - Peixes mortos são encontrados na região do Vale do Suruaca (ANDA - 11/03/2010)

- RJ - 86 toneladas de peixes mortos na Lagoa Rodrigo de Freitas (O Gllobo 27/02/2010)

- RJ - Peixes mortos em Araruama (Big Pop - 26/01/2010) 
- SP - Uma tonelada de peixes mortos no Rio Piracicaba (Guia de Pesca - 10/11/2009)

- AM - Toneladas de peixes mortos em rio no AMAZONAS - (TViG $27 / 11 / 2009$ )

- RO - Mais um desastre ambiental em Rondônia deixa milhares de peixes mortos (Amazonia.org - 20/11/2009)

- PE - Centenas de peixes mortos no Rio Capibaribe (Diário de Pernambuco - 30/09/2009)

- BA - Três toneladas de peixes mortos são encontradas na BA (UOL Mais e Band News - 26/08/2009)

- MG - Mortes de peixes se tornam um problema crônico no São Francisco (Portal Eco Debates - 01/04/2008)

- RS - Peixes mortos no Arroio Castelhano ( Blog Caos de Venâncio Aires - 13/12/2007)

- SP - Uma tonelada de peixes mortos é retirada de rio em SP (Globo.com $-27 / 09 / 2007$ )

- CE - Poluição no Rio Poti mata peixes (Diário do Nordeste $05 / 05 / 2007)$

- RJ - Peixes mortos aparecem na Lagoa da Tijuca/RJ (AmbienteBrasil - $05 / 05 / 2006)$

- SP - Agonia do rio Paraíba (Veja São José - 12/05/2006)

Este pequeno - mas assustador - levantamento não contempla muitos outros desastres semelhantes que não constam na Internet, então, imaginem! Seria possível contabilizar, em números, quanta vida aquática já perdemos em nossos rios, lagos, lagoas...?

Estamos profundamente consternados com esta situação.

Como é uma triste história que se repete, então, repito também um texto escrito em 2006 quando ocorreu a primeira mortandade de peixes no Rio dos Sinos: 


\section{Crianças e Peixes}

Uma menina com seus quatro ou cinco anos de idade depara-se, pela primeira vez, com uma cena que provavelmente levará na lembrança pelo resto da vida: milhares de peixes mortos boiando na superfície do Rio dos Sinos. Seu olhar vago, sua postura, sua inércia diante do que estava vendo naquele sábado à tarde, evidenciaram o nascimento de muitas questões: "O que está acontecendo?", "Quem fez isto?", "Por que estes peixinhos estão todos de barriga para cima, mortos?" - se é que ela já entende o que é a morte. Vai ser bem difícil para ela assimilar o que presenciou. Assim como ela, dezenas de crianças que estavam a bordo do Martim Pescador e que presenciaram a cena em pleno momento de atividades de Educação Ambiental, certamente ficaram sem compreender aquela visão assustadora, além de outras centenas de milhares de crianças que tomaram conhecimento do desastre através dos meios de comunicação.

É urgente apresentar respostas a estas crianças. E o que explicar? Como explicar? Por onde começar uma conversa sobre um assunto tão complexo e difícil até para nós adultos compreendermos?

É uma dura tarefa, porém, necessária: é preciso esclarecer os fatos, aos poucos, e ajudar as crianças a lidarem de forma significativa - e não fantasiosa - com o ocorrido, envolvendo-as em atividades de sensibilização e de reflexão, possibilitando a compreensão de como funciona o ciclo da vida, e de como é delicado - ecossistema frente a nossa forma de viver que reflete a cultura do consumo e da utilização desenfreada dos recursos naturais.

Através das fotos do desastre veiculadas nos meios de comunicação é possível visualizar muito lixo (garrafas pet, embalagens, galões e outras coisas que bóiam), além dos peixes mortos, e, independente de a causa ter sido um fato isolado (que eu não acredito) ou ter sido resposta a uma situação cumulativa de poluição ambiental, é preciso levar respostas a estas crianças, 
Editorial REMOA, Adams, B. G., vol(1), n 1, p. 1-5, 2010.

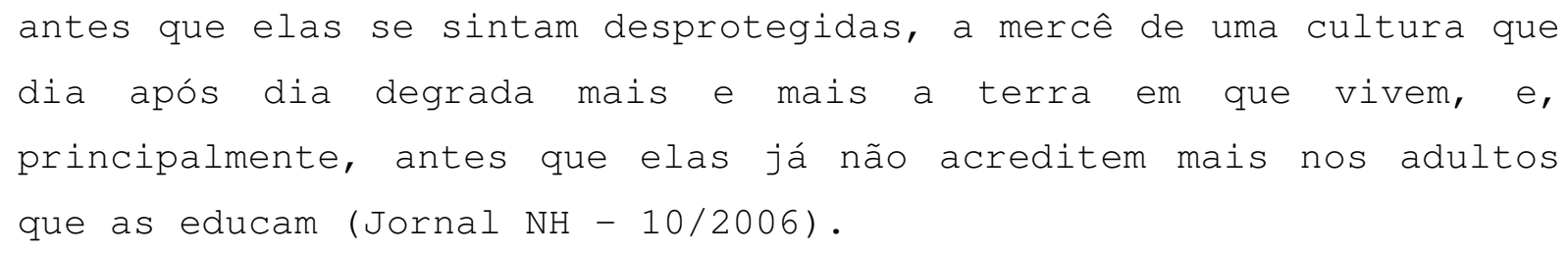

\section{Ria Dos Sinos}

Denise Severgnini (Recanto das Letras)

OTasce em Caraá, cachoeiras belissimas. Oem descendo a serra de mansinho! To Vale, começa seu cruel martírio.. Sixo, indústrias, erosão acentuadíssima OTaka ciliar que sumin de mansinho Peixes mortos, oxigênio em delirio... Jriske fotografia do rio que agoniza... População acorda! Jua ajuda ele precisa! http: / / projetoapoema.blogspot.com/ 